\title{
Infiltration Rates and Sediment Production as Influenced by Grazing Systems in the Texas Rolling Plains
}

\author{
J.J. PLUHAR, R.W. KNIGHT, AND R.K. HEITSCHMIDT
}

\section{Abstract}

Research was initiated in August 1982 at the Texas Experimental Ranch to evaluate effect of selected grazing treatments on watershed condition. Two production scale grazing treatments were sampled on 4 dates over a period of 15 months. Treatments were yearlong continuous graxing stocked at a moderate rate (MC) and a 16-paddock rotational grazing treatment stocked at a heavy rate (RG). In addition, hydrologic conditions in an ungrazed exclosure (EX) and a moderately stocked 4-pasture, 3-herd deferred rotation treatment (DR) were examined during the summer of 1982 . Regression analyses indicated infiltration rates increased and sediment production declined as vegetation standing crop and cover increased, soil bulk density decreased, and soil organic matter and aggregate stability increased. Averaged across the 4 sample dates, sediment production was least $(33 \mathrm{~kg} / \mathrm{ha})$ and infiltration rate greatest $(89 \mathrm{~mm} / \mathrm{hr})$ in the $\mathrm{MC}$ treatment as compared to the RG treatment $(63 \mathrm{~kg} / \mathrm{ha}$ and $82 \mathrm{~mm} / \mathrm{hr})$. Infiltration rates and sediment production in the $R G$ and $D R$ treatments before grazing were not significantly different from those in the MC treatment; however, grazing caused a significant decline in infiltration rates and a significant increase in sediment production in both treatments. Sediment production was least in the exclosure $(23 \mathrm{~kg} / \mathrm{ha})$ while infiltration rates were generally greater and sediment production less in the midgrass communities as compared to the shortgrass communities. All effects were closely related to the effect of the various treatments on vegetation standing crop and cover.

Key words: range watersheds, hydrology, rotational cell grazing, continuous grazing, midgrass, shortgrass

Grazing management is defined as the manipulation of livestock grazing to accomplish a desired result (Soc. Range Manage. 1974). It is a management tool available to increase ranch income while maintaining or improving the range resource (Stoddart et al. 1975) as evidenced by more favorable plant species composition, increased plant and litter cover, and increased plant vigor. Grazing systems affect watershed condition by altering vegetation cover and standing crop, and bulk density, organic matter content, and aggregate stability of soils (Blackburn et al. 1982). Previous research has generally shown that as vegetation cover declines, water infiltration rates decrease and sediment production increases (Klemmedson 1956, Johnston 1962, Whitman et al. 1965, Smith 1967, Rauzi et al. 1968, Brown and Schuster 1969, McCalla et al. 1984). Likewise, as soil bulk density increases and organic matter content and aggregate stability decrease, rate of water infiltration decreases and sediment production increases (Klemmedson 1956, Rhoades et al. 1964, Meeuwig 1970, McGinty et al. 1978). Therefore, grazing management strategies which tend to enhance vegetation cover, reduce soil bulk density, and increase soil organic matter and aggregate stability, tend to enhance watershed condition.

The major objective of this study was to quantify the effects of

Authors are range conservationist, Canadian River Soil and Water Conservation District. Amarillo, Texas 79106; assistant professor, Department of Range Science, Texas A\&M University, College Station 77843; and associate professor, Texas Agricultural Experiment Station, Vernon 76384. At the time of the research, the senior author was research assistant, Department of Range Science, Texas A\&M University.

Research was funded in part by a grant from the E. Paul and Helen Buck Waggoner Foundation, Inc., Vernon, Texas 76384.

Report is published with approval of the Director, Texas Agricultural Experiment Station, as TA-21197.

Manuscript accepted 25 September 1986. a rotational grazing treatment on rangeland hydrologic properties. Specific objectives were to: (1) contrast hydrologic response across 5 grazing treatments in 2 types of plant communities, and (2) quantify the relationship between type of grazing treatment and various soil and vegetational factors as they affect water infiltration rates and sediment production. Our basic hypothesis was that watershed condition would vary among grazing treatments as a function of their effect on various soil and vegetation factors.

\section{Materials and Methods}

\section{Study Area}

The study was conducted at the 2,900-ha Texas Experimental Ranch $\left(99^{\circ} 14^{\prime} \mathrm{W}, 33^{\circ} 20^{\prime} \mathrm{N}\right)$ located in the Rolling Plains natural resource area $16 \mathrm{~km}$ north of Throckmorton, Texas. Annual precipitation averages $680 \mathrm{~mm}$ and is bimodally distributed (Fig. 1).

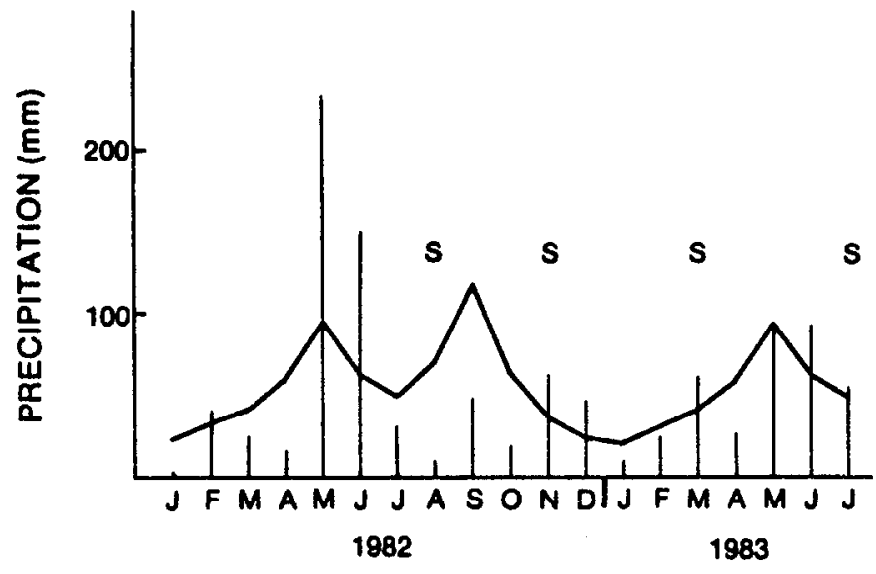

\section{DATE}

Fig. 1. Long-term average (horizontal line) and monthly precipitation (vertical lines) received at Texas Experimental Ranch from April 1982 through August 1983. (s = sample date).

Climate is continental and highly variable. Mean daily temperatures range from $4^{\circ} \mathrm{C}$ in January to $29^{\circ} \mathrm{C}$ in July. Average frost-free growing season is 233 days, extending from March to November.

Vegetation at the ranch is a mixture of mid-and shortgrasses. Dominant midgrasses are sideoats grama [Bouteloua curtipendula (Micxh.) Torr.], a warm-season perennial, and Texas wintergrass [Stipa leucotricha Trin. and Rupr.], a cool-season perennial. Dominant shortgrasses are buffalograss [Buchloe dactyloides (Nutt.) Engelm.] and common curlymesquite [Hilaria belangeri (Steud.) Nash], both warm-season perennials. Soils are primarily clays and clay loams. Dominant range sites are clay loam, clay flat, rocky hills, and loamy bottomland. For a more complete description of the vegetation, soils, and range sites see Heitschmidt et al. (1985).

\section{Treatments}

Grazing treatments included in the study were an ungrazed exclosure (EX), moderately stocked yearlong continuous (MC) and 4-pasture 3-herd deferred rotation (DR) treatments, and a heavily stocked 16 paddock rotational grazing (RG) treatment 
Table 1. Description of grazing treatments sampled during study.

\begin{tabular}{lccccc}
\hline \hline & $\begin{array}{c}\text { Date } \\
\text { initiated }\end{array}$ & $\begin{array}{c}\text { Paddock } \\
\text { size } \\
\text { (ha) }\end{array}$ & $\begin{array}{c}\text { Number } \\
\text { of } \\
\text { cows }\end{array}$ & $\begin{array}{c}\text { Stocking' } \\
\text { rate(ha/ } \\
\text { (cow/yr) }\end{array}$ & $\begin{array}{c}\text { Stocking } \\
\text { density } \\
\text { (au/ha) }\end{array}$ \\
\hline Treatment & 30 & 125 & 3.6 & 4.2 \\
\hline $\begin{array}{l}\text { 14-paddock rotation } \\
\text { (RG-14) }\end{array}$ & Mar. 1981 & 30 & 125 & 3.6 & 12.5 \\
$\begin{array}{c}\text { 42-paddock rotation } \\
\text { (RG-42) }\end{array}$ & Mar. 1982 & 10 & 125 & & \\
$\begin{array}{l}\text { 4-pasture, 3-herd } \\
\text { deferred rotation } \\
\text { (DR) }\end{array}$ & 1959 & 110 & 25 & 5.8 & 0.3 \\
$\begin{array}{c}\text { Yearlong continuous } \\
\text { (MC) }\end{array}$ & 1959 & 240 & 41 & 5.8 & 0.2 \\
$\begin{array}{c}\text { Ungrazed exclosure } \\
\text { (EX) }\end{array}$ & 1959 & 5 & 0 & - & - \\
\hline
\end{tabular}

'Based on total area of all paddocks/pastures in RG and DR treatments.

(Table 1). Originally the RG treatment consisted of 14 paddocks. In 1982, one 30-ha paddock was subdivided into three 10-ha paddocks. Sample plots were subsequently located in one 30-ha paddock and one 10-ha paddock for the purpose of evaluating the effect of RG on watershed condition at 2 livestock densities. Hereafter, the RG-14 designation refers to plots in the 30-ha paddock with a livestock density equal to a 14-paddock system and RG-42 refers to plots in the 10-ha paddock which provided a livestock density equal to a 42-paddock system. Prior to this study the RG treatment was under a high intensity-low frequency system which was started in 1973. Wood and Blackburn (1981a, 1981b) reported that this grazing system had hydrologic properties similar to the MC treatment. All treatments were stocked yearlong with crossbred cows. Stocking rates in all treatments were constant. Rate of rotation of the $R G$ herd varied seasonally and ranged from about 30 to 65 days. Length of graze ranged from 0.7 days in RG-42 during a 30-day cycle to 4 days in RG-14 during a 60-day cycle.

\section{Sampling Scheme}

Two plant communities (midgrass and shortgrass) were sampled within each treatment on a single soil series, the Nuvalde series. The Nuvalde series is a member of the fine-silty, mixed, thermic family of Typic Calciustolls. It is a deep, well-drained, moderately permeable soil located on nearly level uplands. Range site classification is clay loam. This series was selected for study because it occurred in all treatments. The midgrass communities were dominated by sideoats grama and Texas wintergrass. Buffalograss and common curly-mesquite were the dominant species in the shor:grass communities. The ungrazed exclosure contained no shortgrass community. Following the first sample date, only the midgrass plant community was sampled. The DR and RG treatment paddocks were sampled immediately prior to and after grazing. The MC and RG treatments were sampled 4 times over a 1-year period (Fig. 1). The EX and DR treatments were sampled only on the first date.

\section{Methods}

A rainfall simulator similar to that described by Meyer and Harmon (1979) was used to measure infiltration rates in ten .71 $X$ $.71 \mathrm{~m}\left(0.5 \mathrm{~m}^{2}\right)$ randomly placed plots per treatment per sample date per vegetation type. The simulated rainfall had a drop size distribution and kinetic energy similar to natural storms of the same size. Plot areas $\left(1 \mathrm{~m}^{2}\right)$ were prewet with $100 \mathrm{l}$ of water using a mist-type sprinkler system to remove antecedent soil moisture differences prior to sampling. The mist-type nozzle was used to reduce possible raindrop impact. After wetting, plots were covered with plastic tarps and allowed to drain to field capacity (about 24 hours). Simulated rainfall was applied for 30 minutes at a rate of 110 $\mathrm{mm} /$ hour to produce runoff from all plots. Wind screens were used to minimize raindrop drift. Infiltration rates were calculated as the difference between the amount of applied rainfall and runoff over the 30-minute period. A 1-liter subsample of thoroughly mixed runoff water was collected from each sample plot to estimate sediment production. Total sediment production $(\mathrm{kg} / \mathrm{ha})$ was determined after filtering the entire subsample through a \#1 Whatman filter paper and drying it at $150^{\circ} \mathrm{C}$.

Percentage bareground and vegetation cover were visually estimated in each sample plot. Vegetative cover was estimated by plant species. Standing crop of grasses and forbs was determined by clipping at the soil surface. After clipping, litter biomass was collected by hand. All biomass was air dried at $60^{\circ} \mathrm{C}$ to a constant weight and weighed. Soil water content and bulk density were determined to a depth of $30 \mathrm{~mm}$ prior to each simulated rainfall event using two 60 -mm diameter (Black 1965) cores. A soil sample from the top $80 \mathrm{~mm}$ of the soil profile was also collected from within each plot following simulated rainfall to be used for soil texture, aggregate stability, and organic matter determinations. Texture was determined by the hydrometer method (Bouyoucos 1962), aggregate stability by the wet sieve method (Kemper and Kock 1965), and organic matter by the Walkley-Black method (Walkley and Black 1934). Surface roughness was estimated for each plot using a 10-pin frame with pins placed $60 \mathrm{~mm}$ apart (Kincaid and Williams 1966). The frame was placed at 3 equal intervals across each plot. Standard deviations of pin heights was used as an index of surface roughness.

\section{Statistical Analyses}

Data were statistically analyzed using 2-way and 3-way analysis of variance models. Prior to analysis, all data were tested for normality using skewness and kurtosis tests. Sediment production was transformed (natural $\log$ ) to fit a normal distribution. The nontransformed data will be presented in the results. Duncan's multiple range tests were utilized for mean separation. Within treatment variation (variation among subplots) was allocated to the residual for testing differences among treatments. Forward stepwise multiple regression procedures were used to generate predictive equations for infiltration rate and sediment production. All significant differences are at $P \leq 0.05$.

\section{Results and Discussion}

\section{Rotational and Yearlong Continuous Grazing}

Statistical analyses of infiltration rates indicated significant treatment, date, and treatment-by-date interaction effects. Averaged across dates, infiltration rate was greatest in the MC treatment though only significantly greater than after grazing in the RG-14 treatment (Table 2). Average infiltration rate declined in both RG treatments following grazing. The declines, however, were not statistically significant. Differences among treatments were related to differences in controlling factors particularly percentage bareground and total herbaceous standing crop (Table 2).

Infiltration rates in all treatments generally followed similar seasonal patterns (Table 3) with average infiltration rates least in spring (March 1983) and greatest in fall (November 1982). However, causal relationships were difficult to quantify because aggregate stability, surface roughness, litter cover and standing crop, and grass and total standing crop were least in March 1983 when soil bulk density, soil organic matter, and grass cover were greatest relative to the three other sample dates (Table 3 ). The treatmentby-date interaction effects were related to minor seasonal differences among grazing treatments (Table 4).

Statistical analyses of the sediment production data showed a significant grazing treatment effect (Table 2) but no date (Table 3) or date-by-treatment interaction effects. Sediment production increased significantly in both RG treatments following grazing but neither treatment was significantly different from the MC treatment prior to grazing. These differences emphasize the dynamic effect that the RG treatment had on watershed condition relative to sediment production. Generally, grazing in the RG treatments reduced vegetation cover and standing crop while increasing litter cover and bare ground. 
Table 2. Mean values $(n=40)$ for measured variables in 3 grazing treatments averaged across 4 dates.

\begin{tabular}{|c|c|c|c|c|c|}
\hline \multirow[b]{3}{*}{ Variable } & \multicolumn{5}{|c|}{ Grazing treatment 1} \\
\hline & \multicolumn{2}{|c|}{ RG-14 } & \multicolumn{2}{|c|}{ RG-42 } & \multirow[b]{2}{*}{ MC } \\
\hline & Before & After & Before & After & \\
\hline \multicolumn{6}{|l|}{ Vegetation } \\
\hline Bareground $(\%)$ & $20 b^{2}$ & $26 \mathrm{~b}$ & $12 c$ & $23 \mathrm{ab}$ & $9 c$ \\
\hline Grass cover $(\%)$ & $47 b$ & $50 c$ & $64 a$ & $50 c$ & $60 \mathrm{ab}$ \\
\hline Forb cover $(\%)$ & $3 a b$ & lb & $2 b$ & lb & $4 a$ \\
\hline Litter cover $(\%)$ & $20 c$ & $23 b c$ & $22 b c$ & $26 a b$ & $28 \mathbf{a}$ \\
\hline Total vegetation & $80 \mathrm{~b}$ & $74 c$ & $88 a$ & $77 \mathrm{bc}$ & $92 a$ \\
\hline Grass standing & & & & & \\
\hline $\operatorname{crop}(\mathrm{kg} / \mathrm{ha})$ & $2244 b$ & $2188 b$ & $2644 a$ & $2010 \mathrm{~b}$ & $2198 b$ \\
\hline $\begin{array}{l}\text { Forb standing } \\
\text { crop }(\mathrm{kg} / \mathrm{ha})\end{array}$ & $70 \mathrm{a}$ & $27 a$ & $108 \mathbf{a}$ & $17 a$ & $144 a$ \\
\hline Litter standing & & & & & \\
\hline $\begin{array}{l}\text { crop (kg/ha) } \\
\text { Total standing }\end{array}$ & $1241 \mathrm{~b}$ & $1329 b$ & $1400 \mathrm{~b}$ & $1541 \mathrm{~b}$ & $2842 a$ \\
\hline $\operatorname{crop}(\mathrm{kg} / \mathrm{ha})^{3}$ & $3555 b$ & $3544 b$ & $4152 b$ & $3568 \mathrm{~b}$ & $5184 a$ \\
\hline \multicolumn{6}{|l|}{ Soil } \\
\hline Bulk density $\left(\mathrm{g} / \mathrm{cm}^{3}\right)$ & $1.2 \mathrm{a}$ & $1.1 \mathrm{a}$ & $1.2 \mathrm{a}$ & $1.2 \mathrm{a}$ & $1.1 \mathrm{a}$ \\
\hline Organic matter $(\%)$ & $6.3 \mathrm{ab}$ & $4.4 \mathrm{c}$ & $6.7 a$ & $5.7 \mathrm{~b}$ & $6.5 a$ \\
\hline Aggregate stability (\%) & $68 \mathrm{a}$ & $65 \mathrm{a}$ & $68 a$ & $70 \mathrm{a}$ & $72 a$ \\
\hline $\begin{array}{l}\text { Surface roughness } \\
(\mathrm{mm})\end{array}$ & $6.2 \mathrm{a}$ & $6.2 \mathrm{a}$ & $6.4 a$ & $6.4 a$ & $7.4 a$ \\
\hline $\begin{array}{l}\text { Infiltration rate } \\
(\mathrm{mm} / \mathrm{hr})\end{array}$ & $87 \mathrm{ab}$ & $77 \mathrm{~b}$ & $85 \mathrm{ab}$ & $78 \mathrm{ab}$ & $89 a$ \\
\hline $\begin{array}{l}\text { Total Sediment } \\
\text { production }(\mathrm{kg} / \mathrm{ha})\end{array}$ & $52 b$ & $85 a$ & $29 b$ & $85 a$ & $33 b$ \\
\hline
\end{tabular}

'See Table 1 for treatment identification.

2Means in a row followed by same letter are not significantly different at $P \leq 0.05$,

${ }^{3}$ Grass + forb + litter.

Table 3. Mean values $(n=50)$ for measured variables on 4 sample dates averaged across RG-14, RG-42, and MC grazing treatments.

Date

Variable

Aug. 1982 Nov. 1982Mar. 1983July 1983

Vegetation

Bareground (\%)

Grass cover (\%)

Forb cover (\%)

Litter cover (\%)

Total vegetation cover $(\%)^{2} \quad 83 a$

Grass standing crop (kg/ha) 2473a

Forb standing crop (kg/ha) $89 \mathrm{a}$

Litter standing crop ( $\mathrm{kg} / \mathrm{ha}) \quad 1722 \mathrm{a}$

Total standing crop $(\mathrm{kg} / \mathrm{ha}) \quad 4284 \mathrm{a}$
$17 \mathrm{a}^{1}$

$55 \mathrm{bc}$

$19 a$
$56 b$

$9 \mathrm{a}$

$17 \mathrm{a}$

$63 a$

$23 \mathbf{b}$

$81 \mathrm{a}$

2301a

$15 \mathrm{a}$

$1721 \mathrm{a}$

$4039 \mathrm{ab}$
Table 4. Infiltration rates ( $\mathrm{mm} / \mathrm{hr}$ ) for 3 grazing treatments on 4 dates.

\begin{tabular}{lllll}
\hline \hline & \multicolumn{5}{c}{ Date } \\
\cline { 2 - 5 } Treatment $^{1}$ & Aug. 1982 & Nov. 1982 & Mar. 1983 & July 1983 \\
\hline RG-14 & & & \\
Before & $95 a(x)^{2}$ & $96 a b$ & $84 a(y)$ & $72 b(z)$ \\
After & $64 b(z)$ & $87 b c(x)$ & $72 a(y)$ & $82 a b(x)$ \\
RG-42 & & & & \\
Before & $81 a(y)$ & $95 a b(x)$ & $69 a(z)$ & $94 a(x)$ \\
After & $85 a(x)$ & $101 a(x)$ & $59 a(y)$ & $68 b(x y)$ \\
MC & $90 a(x)$ & $83 c(y)$ & $84 a(y)$ & $99 a(x)$ \\
\hline
\end{tabular}

ISee Table 1 for treatment identification

2Means in a row or within a column followed by same letter within parentheses.

Wood and Blackburn (1981b) at the Texas Experimental Ranch, differences were significant when averaged across grazing treatment. Sediment production in our study averaged 49 and $55 \mathrm{~kg} / \mathrm{ha}$ in the midgrass and shortgrass communities, respectively, as compared to 39 and $95 \mathrm{~kg} / \mathrm{ha}$, respectively, in their study. We attribute these differences primarily to climatic differences among years. For example, in 1982 growing conditions were extremely favorable (Fig. 1) relative to the growth of warm-season grasses. As a result there were fewer differences between plant communities in amount of bareground and vegetation cover in this study than in their study.

\section{Rotational, Yearlong Continuous, and Deferred Rotation Grazing}

The effect of livestock grazing in the RG and DR treatments was generally reflected by a reduction in total vegetation cover and total standing crop and an increase in amount of bareground regardless of type of plant community. The resultant effect was rate of water infiltration generally declined and sediment production generally increased in both types of plant communities following grazing (Table 5). There were no significant differences among treatments in infiltration rate when the MC, before-grazing RG and DR treatments, and EX were compared. The EX and MC treatment had the lowest sediment production, while generally the after grazing treatments had the highest. Wood and Blackburn, (1981a, 1981b) working at the same location, reported similar results when comparing infiltration rate and sediment production on a Leeray clay in the MC, DR, and EX treatments.

Table 5. Mean $(m=10)$ infiltration rates $(\mathrm{mm} / \mathrm{hr})$ and sediment produc tion (kg/ha) for 2 types of plant communities in 5 grazing treatments.

\begin{tabular}{|c|c|c|c|c|}
\hline \multirow[b]{2}{*}{ Treatment } & \multicolumn{2}{|c|}{ Infiltration rate } & \multicolumn{2}{|c|}{ Sediment production } \\
\hline & Midgrass & Shortgrass & Midgrass & Shortgrass \\
\hline $\begin{array}{l}\text { RG-14 } \\
\text { Before grazing } \\
\text { After grazing }\end{array}$ & $\begin{array}{l}95 a^{2} \\
64 b\end{array}$ & $\begin{array}{l}75 a \\
55 b\end{array}$ & $\begin{array}{l}37 \mathrm{bc} \\
105 \mathrm{a}\end{array}$ & $\begin{array}{l}63 \mathrm{ab} \\
105 \mathrm{a}\end{array}$ \\
\hline $\begin{array}{l}\text { RG-42 } \\
\text { Before grazing } \\
\text { After grazing }\end{array}$ & $\begin{array}{l}81 a b \\
85 a\end{array}$ & $\begin{array}{l}86 a \\
79 a\end{array}$ & $\begin{array}{l}41 \mathrm{bc} \\
75 \mathrm{ab}\end{array}$ & $\begin{array}{l}61 \mathrm{ab} \\
53 \mathrm{ab}\end{array}$ \\
\hline $\begin{array}{l}\text { DR } \\
\text { Before grazing } \\
\text { After grazing }\end{array}$ & $\begin{array}{l}86 a \\
81 a b\end{array}$ & $\begin{array}{l}80 a \\
68 a b\end{array}$ & $\begin{array}{l}28 \mathrm{c} \\
71 \mathrm{ab}\end{array}$ & $\begin{array}{l}45 b \\
54 b\end{array}$ \\
\hline MC & $89 a$ & $85 a$ & $35 \mathrm{c}$ & $30 \mathrm{~b}$ \\
\hline EX & $88 a$ & -3 & $23 \mathrm{c}$ & - \\
\hline Mean & 84 & 75 & 49 & 55 \\
\hline
\end{tabular}

ISee Table 1 for treatment identification.

2Means in a column followed by same letter are not significantly different at $P \leq 0.05$. ${ }^{3}$ The shortgrass plant community did not occur in the exclosure.
Soil

Bulk density $\left(\mathrm{g} / \mathrm{cm}^{3}\right)$

Organic matter $(\%)$

Aggregate stability (\%)

Surface roughness (mm)

Infiltration rate $(\mathrm{mm} / \mathrm{hr})$

Total sediment production

$$
\text { (kg/ha) }
$$

$$
54 a
$$

$55 \mathrm{a}$

$73 a$

$57 \mathrm{a}$

IMeans within a row followed by same letter are not significantly differet at $P \leq 0.05$. ${ }^{2}$ Grass + forb + litter.

\section{Type of Plant Community}

Water infiltration rates were significantly greater in midgrass $(84$ $\mathrm{mm} / \mathrm{hr}$ ) than shortgrass communities $(75 \mathrm{~mm} / \mathrm{hr}$ ) when averaged across grazing treatments (Table 5). These findings agree with the findings of Wood and Blackburn (1981a). Although the effect of type of plant community on sediment production (Table 5) was not as clearly discernible in this study as in the study conducted by 


\section{Predictive Models}

The two predictive models from the pooled data developed were:

$Y_{1}=77.32-0.46 X_{1}+0.004 X_{2} \quad R^{2}=0.16$ df $=339$

$Y_{1}=14.7+0.18 X_{1}-0.0044 X_{2} \quad R^{2}=0.20 \quad d f=284$

Where $Y_{1}=$ rate of water infiltration $(\mathrm{mm} / \mathrm{hr})$

$\mathrm{Y}_{2}=$ total sediment production $(\mathrm{kg} / \mathrm{ha})$

$\mathrm{X}_{1}=$ percentage bareground $(\%)$

$\mathrm{X}_{2}=$ total vegetation standing crop $(\mathrm{kg} / \mathrm{ha})$

Amount of bareground was the first variable selected in both models, accounting for $12 \%$ of the variation in the infiltration model and $16 \%$ in the sediment production model. The 2 models substantiate that as bareground increased in this study, infiltration rates decreased and sediment production increased. Likewise, as amount of vegetation standing crop increased, infiltration rates increased and sediment production declined. The addition of percentage sand content in the soil and aggregate stability to the infiltration model increased the $R^{2}$ to 0.20 while the addition of aggregate stability and surface roughness to the sediment production model increased the $R^{2}$ to 0.24 .

Although our final $R^{2}$ values are less than those reported by Wood and Blackburn (1981a, 1981b), both models were highly significant $(P<0.0001)$. The $R^{2}$ values, even though they were low, still helped to explain the factors affecting infiltration rates and sediment production. We chose not to develop our models as a function of type of grazing treatment, plant community, or season of year because our basic objective was to identify the most important factors contributing to differences in watershed condition regardless of grazing treatment, type of vegetation, or season of year. Both models clearly indicate amount of bareground and vegetation standing crop were the 2 major variables affecting watershed condition in this study.

\section{Conclusions}

Basing our conclusions on the results of this study, we accept our basic hypothesis that watershed condition will vary among grazing treatments as a function of their effect on various soil and vegetative factors. We further conclude that differences among grazing treatments are directly related to their effect on amount of bare ground. Grazing treatments which cause a reduction in vegetative cover and standing crop, with a corresponding increase in bare ground, tend to reduce water infiltration rates and concurrently enhance sediment production. This may be realized over the longterm by inducing a change in plant species composition from midgrass to shortgrass dominated communities or over the shortterm by consuming and/or trampling the available vegetation standing crop. Further, we find no evidence from the results of this study that would suggest any association exists between watershed condition in a rational grazing treatment and number of paddocks. There were no benefits of RG compared to MC grazing when considering the measured hydrologic parameters.

\section{Literature Cited}

Black, C.A. (ed.). 1965. Methods of soil analysis. Amer. Soc. of Agron. Series No. 9. Madison, Wis.

Blackburn, W.H., R.W. Knight, and M.K. Wood. 1982. Impact of grazing on watershed: a state of knowledge. Texas Agr. Exp. Sta. MP-1496.

Bouyoucos, G.H. 1962. Hydrometer method for making particle size analysis of soil. Agron. J. 54:464-465.

Brown, J.W., and J.L. Schuster. 1969. Effects of grazing on a hardland site in the Southern High Plains. J. Range Manage. 22:418-423.

Heitschmidt, R.K., S.L. Dowhower, R.A. Gordon, and D.L. Price. 1985. Reponse os vegetation to livestock grazing at the Texas Experimental Ranch. Tex. Agr. Exp. Sta. Bull. 1515.

Johnston, A. 1962. Effects of grazing intensity and cover on water intake rate of fescue grassland. J. Range Manage. 15:79-82.

Kemper, W.D., and E.J. Koch. 1965. Aggregate stability of soils from the western portions of the United States and Canada. USDA Tech. Bull. 1355.

Kincaid, D.R., and G. Williams. 1966. Rainfall effects on soil surface characteristics following range improvements. J. Range Manage. 19:346351 .

Klemmedson, J.O. 1956. Interrelations of vegetation, soils, and range conditions induced by grazing. J. Range Manage. 9:134-138.

McCalla, G.R., W.H. Blackbum, and L.B. Merrill. 1984. Effects of livestock grazing on infiltration rates, Edwards Plateau of Texas. J. Range Manage. 37:265-268.

McGinty, W.A., F.E. Smeins, and L.B. Merrill. 1978. Influence of soil, vegetation, and grazing management on infiltration rate and sediment production of Edwards Plateau rangeland. J. Range Manage. 32:33-37.

Meeuwig. R.0. 1970. Infiltration and soil erosion as influenced by vegetation and soil in northern Utah. J. Range Manage. 23:183-188.

Meyer, L.D., and W.C. Harmon. 1979. Multiple intensity rainfall simulator for erosion research on row side slopes. In: Trans. of the ASAE, Amer. Soc. Agr. Eng., St. Joseph, Mich. 22:100-103.

Rauzi, F., C.L. FLy, and E.J. Dyksterhuis. 1968. Water intake on midcontinental rangelands as influenced by soil and plant cover. USDA Tec. Bull. 1390.

Rhoades, E.D., L.F. Locke, H.M. Taylor, and E.H. McIlvain. 1964. Water intake on a sandy range as affected by 20 years of differential cattle stocking rates. J. Range Manage. 17:185-190.

Smith, D.R. 1967. Effects of cattle grazing on a ponderosa pine-bunchgrass range in Colorado. USDA Tech. Bull. 1371.

Society of Range Management. 1974. A glossary of terms used in range management. Soc. Range Manage. Denver, Colo.

Stoddart, L.A., A.D. Smith, and T.W. Box. 1975. Range management. McGraw-Hill Book Co., New York.

Walkley, A., and A.J. Black. 1934. An examination of the Deqtjareff method for determining soil organic matter and a proposed modification of the chromic acid titration method. Soil Sci. 37:29-38.

Whitman, W.C., D. Zeller, and A.J. Bjugstad. 1965. Grazing affects coverreduces soil water intake. Crops and Soils 17:23-34.

Wood, M.K., and W.H. Blackburn. 1981a. Grazing systems: their influence on infiltration rates in the Rolling Plains of Texas. J. Range Manage. 34:331-335.

Wood, M.K., and W.H. Blackburn. 1981b. Sediment production as influenced by livestock grazing on the Texas Rolling Plains. J. Range Manage. $34: 228-231$. 